\title{
5 Social Enterprise in Hungary
}

Concepts, Models and Institutions

\author{
Éva G. Fekete, László Hubai, \\ Julianna Kiss and Melinda Mihály
}

\section{Introduction $^{1}$}

The concept of social enterprise (SE) was introduced in Hungary more than two decades ago by international development organisations, but remained little known and seldom used for a long time. This has begun to change recently, however. Non-profit organisations, which had not relied on the concept prior to the appearance of these development organisations in the country, increasingly started looking at social entrepreneurship and its potential for income generation. The private sector had not hitherto used the concept either because, for a long time, businesses were not thought to be responsible for social issues, and they lacked connections with the non-profit sector (Tóth et al. 2011: 6), but in recent years, some market-based organisations showing interest in the sector have appeared. Until recently, the focus in public policies was not on social enterprise, but rather on the social economy and the creation of social cooperatives, mainly supported through EU-funded programmes; in the new Hungarian Partnership Agreement for the 2014-2020 Programming Period, though, the term "social enterprise" was explicitly used for the first time. Regarding the academic field, only one university course on social enterprise existed for several years (it had been launched in 2006); today, however, several universities offer courses and conduct research on this topic. Multiple stakeholders thus appear to be increasingly interested in the concept, and a number of organisations now identify themselves as social enterprises.

\section{The Concept of Social Enterprise in Hungary}

The relatively new concept of social enterprise can be connected to various concepts, such as those of "non-profit sector", "civil society" and "social economy", which have a longer history and are usually better understood in Hungary. The concept of non-profit sector, which emphasises the non-profit distribution element, and that of civil society, which 
stresses the active involvement of citizens and democratic participation, (re)emerged after the regime change in 1989; they have been used to describe socio-economic organisations that do not belong to the forprofit sector or to the public one (Kuti 1998). As for the term social economy, it entered public and scientific discourse at the time of EU accession; this concept highlights the presence, in the organisations making up this sector, of economic elements besides social ones, and it stresses the importance of employment generation (Frey 2007: 2). The concepts of community enterprise and community development also appear in research about local or rural development highlighting the importance of participative governance within the organisations (Vágvölgyi 2012; Mészáros 2013). Researchers in the field of business ethics, responsible enterprises or corporate social responsibility (CSR) have also contributed to the conceptualisation of social enterprise in Hungary, stressing in particular the importance of ethical decision-making (see Pataki and Radácsi 2000). The concepts of third sector (focusing on the independence of the sector) or solidarity economy (challenging the dominance of the market economy) have had only limited influence in Hungary so far. There are often no or only minor differences between the Hungarian definitions of these concepts and their international definitions.

Regarding the concept of social enterprise in particular, there is no single and widely accepted definition in Hungary, nor is there a unified regulatory framework. It is also common to use the term without defining it (G. Fekete, Lipták et al. 2014: 22). Moreover, the word "social" can be translated in two different ways in Hungarian: as "szociális", which has a somewhat narrower meaning, referring to the concept of "social" mostly in connection with funding and welfare-related issues, or as "társadalmi", which has a broader meaning of "connected to society". While the former was often used in the past, experts have recently started using the latter.

Different definitions of social enterprise coexist in Hungary; they emphasise different dimensions and can be connected to different international schools of thought. G. Fekete emphasises the economic, social and civic dimensions of the organisations-three dimensions that are also highlighted by the EMES International Research Network-and stresses in particular their role in employment generation (G. Fekete 2007: 64). In the first $\mathrm{PhD}$ dissertation written on the topic of social enterprise, Petheó (2009) used the CONSCISE definition of social enterprise (European Commission 2007), developed partially by EMES researchers (Petheô 2009: 10). Financial sustainability and innovation are emphasised in the definition put forward by the SE development agency NESsT, which describes social enterprises as organisations consciously organising and operating entrepreneurial activity in order to solve societal challenges in an innovative way (Tóth et al. 2011: 5). To the extent that NESsT places a strong emphasis on earned-income strategies implemented by 
organisations and underlines the importance of innovation, it could be considered to represent both the earned-income school of thought and, to some extent, the social-innovation school of thought in Hungary. Ashoka, another international SE development agency present in Hungary, focuses on social entrepreneurs, that is, individuals who put forward and implement system-changing solutions to the world's most urgent social problems (Ashoka 2015); Ashoka represents the socialinnovation school of thought in Hungary.

The definition that is most widely used by public authorities and programme managers is one that has been put forward by the European Commission (G. Fekete, Vicze et al. 2014: 1). In the new Hungarian Partnership Agreement for the 2014-2020 Programming Period, support to social enterprise is explicitly mentioned, and an official definition is also given for the first time in a policy document; according to this definition, social enterprises are "those non-profit and civil-society organisations that have viable economic goals in addition to their social objectives; the profit of their business activities is reinvested for social objectives; and they implement the principle of participatory decision-making in their budgets and organisational functioning" (Ministry for National Economy 2015: 6; authors' own translation). In current public policy, the issue of employment is of central importance; restrictions based on legal forms are also present.

Despite the diversity of present approaches, critical debates about the concept of social entrepreneurship-comparing for instance the positive and negative aspects of the different definitions-have been limited in Hungarian academia so far. ${ }^{2}$ The definitions currently used in Hungary are adopted from Western European (EU-related) or US schools of thought, and their adaptability to the specific situation of Hungary has not yet been thoroughly discussed.

\section{SE Models}

Based on legal forms, sectoral affiliation, social aims, fields of economic activity as well as scale and form of employment, six major models of social enterprise can be distinguished in Hungary. In the following section, the main characteristics of these models are presented.

\subsection{Public-Service-Provision Social Enterprises}

Public-service-provision social enterprises are non-profit organisations with close ties to the public sector. Indeed, these social enterprises are usually not founded by citizens but by the state or by organisations close to the state; moreover, they provide services that were formerly a public responsibility, and they thus receive statutory state support. ${ }^{3}$ They may also get engaged in the private market through the production of 
goods or the provision of services. Such organisations operate mainly within the social and public-utility sectors; they are, for example, nonprofit organisations employing people with altered working abilities, or foundations operating family day-care centres or old people's homes. They are typically legally registered as non-profit companies (previously, public-benefit companies) or foundations. As a result of local governments frequently being among their founders or members, this type of social enterprise, which is a dominant model in the SE field in Hungary, is often not autonomous (in the sense of being independent from the state in terms of decision-making).

\subsection{Enterprising CSOs}

In order to ensure their financial sustainability and reach their social goals, civil-society organisations (CSOs-i.e. mainly foundations and associations) have recently started to increasingly engage in economic activities. The business activity of enterprising CSOs is intended to complement private donations and grant-based public funding. This economic activity (e.g. book publishing, training, consultancy, running a charity shop, selling organic products and child care) is thus mainly a financial tool to reach the original social aims. In many cases, though, such activity only generates a small amount of additional income, thus helping to cover the overall costs of the organisation only to a small extent. Paid employment is limited; most tasks are performed by volunteers and a small number of paid managers. It often happens that traditional CSOs set up a separate legal entity—namely, a "non-profit Ltd.", as this legal form is better suited for carrying out entrepreneurial activities. Enterprising CSOs do not necessarily consider themselves social enterprises, may find accessing public support challenging and often struggle with financial sustainability problems.

\subsection{Work-Integration CSOs}

Work-integration CSOs are non-profit legal entities set up by private citizens. Among these enterprises' target groups, different disadvantaged social groups can be identified-for example women, ethnic minorities (especially Roma people) and disabled people. These organisations can also receive statutory support for the employment of people with altered working abilities. Some of these enterprises aim at the employment of their target groups; others facilitate income generation by people from their target groups without employing them themselves (e.g. through training them in fields, such as gardening, farming and sewing). The number of employees can range from a few people to several hundreds. As the main aim of these organisations is to integrate marginalised people through work, they have a relatively high reliance on public funding, 
and it becomes challenging for them when funding is not statutory but project-based. This category of social enterprise includes organisations with various legal forms: not only foundations, associations but also social cooperatives set up by civilians (prior to the adoption of the latest pieces of legislation about social cooperatives-see Section 3.1) and non-profit companies. Changes in policies supporting work-integration CSOs have negatively affected the financial resources available to these organisations; as a result, these social enterprises strive for a stronger market orientation, but their efforts are not always successful. As funding on a statutory basis is scarce, work-integration CSOs are dependent on project-based grants, resulting in management challenges or frequent changes in activities.

\subsection{Local-Development Community Enterprises}

Local-development community enterprises implement local economicdevelopment programmes in an integrated, multifunctional way, usually with the direct involvement of local governments. Some kind of local product or an activity serving the operation or development of the village/town is at the core of their activity. They mostly operate in rural areas lacking small- and medium-sized enterprises and they are developed with a view to providing certain public services. They take legal forms that are recognised by public bodies (such as those of foundation or social cooperative) and thus enable them, for instance, to apply for grants or statutory support. Social enterprises in this category focus on community development, but since the activities are often initiated and coordinated by the local municipalities, the participatory nature of the decision-making processes may be weak, and a local citizen-often the mayor-usually plays a crucial role in the initiative. These social enterprises can also be connected to public-work programmes managed by local governments, which are often criticised (see endnote 22). Another sensitive point is their possible negative impact on local mainstream enterprises. Indeed, due to the financial support they receive or to the opportunities they have to employ people through public-work programmes, local-development community enterprises have lower production costs than other local enterprises.

\subsection{Social Start-Ups}

The business activity of social start-ups is rooted in business ethics. Their social aim directly influences their economic activity, which facilitates the development of an economy based on a greater degree of social justice and environmental consciousness. Both non-profit and for-profit companies putting emphasis on philanthropic solidarity and innovation can be included in this category. Social start-ups often emerge in the fields of IT, waste management, recycling, culture and transportation. The 
democratic nature of these organisations may be weak, as a result of the emphasis on leadership and effectiveness in decision-making. Employment is not a major goal for social start-ups, and the number of employees in these organisations is determined by economic necessity.

\subsection{Solidarity-Economy Initiatives}

Solidarity-economy enterprises emerge in both rural and urban areas and implement or are constantly looking for transformative social innovation (Avelino et al.2019), that is, alternative answers to current problems, going beyond modernism and capitalism to redefine traditional communitybased practices. Mobilised by the forthcoming climate catastrophe and the management of the global economic crisis, which put increasing pressure on social reproduction, ${ }^{4}$ three movements started to converge in developing a solidarity economy: (1) left-wing movements criticising the operation of the global capitalist economy; (2) "green" social movements criticising the destruction of ecosystems; and (3) feminist movements that act against the exploitation of reproductive labour (Gagyi 2020). A new consensus seems to emerge among these social movements; it contrasts the vision of a democratic global economy serving the sustainability of social and ecological systems with the limitless capitalist accumulation (economic growth) that results in climate catastrophe and reproductive crisis ${ }^{5}$ (ibid.). Reciprocity, participation and democratic decision-making play a defining role in the principles of operation of solidarity-economy enterprises. These enterprises aim to channel various resources, such as re-politicised informal work, marketbased income, public support or grants supporting the development of an alternative economy. They have economic activities that satisfy the needs of their members, who are often a group of friends and/or neighbours. However, the Hungarian solidarity economy aims to become not simply a multitude of democratically organised, environmentally conscious economic units; it also aims to become a wide economic network, linking solidarity-economy enterprises from various fields of the economy (Gagyi et al. 2020; website of the Centre for the SolidarityEconomy Network in Hungary ${ }^{6}$ ). Solidarity-economy enterprises may operate beyond the framework of the market economy; local exchange trading systems (LETS), and in particular time banks or re-politicised kalákas, can be examples of such enterprises. ${ }^{7}$

In the proposed typology, the different models are usually not connected to specific legal forms: all legal forms appear in almost all types of social enterprise, irrespective of the sectoral affiliation or social aim. Paid work can also be present in all models, though the largest potential for employment is observed in those models where employment is subsidised by the state-namely in public-service-provision social enterprises, workintegration CSOs and local-development community enterprises. None 
of the models fully meets all the indicators of the EMES approach to social enterprise: central, state or local governmental influence (primarily through public funding) can be excessive in public-service provision social enterprises, work-integration CSOs and local-development community enterprises, which in turn can lead to a loss of autonomy; the entrepreneurial character of enterprising CSOs is often weak; the nature of operation in social start-ups is usually not democratic, and these initiatives are often characterised by a market bias. And though solidarityeconomy initiatives are close to the EMES ideal-type social enterprise, their epistemologies are less diverse than in the EMES Network. While EMES researchers allow an epistemological plurality in SE research (e.g. in the ICSEM project), the epistemologies of the emerging solidarity-economy initiatives in Hungary are more integrated, in the sense that they generally involve an ideological stance that envisions socioeconomic development beyond capitalism.

\section{Institutional Development}

SE activities-not-for-profit economic activities in both the substantive and formal economic senses-have a long history and are largely connected to the non-profit and cooperative (including the newly institutionalised social-cooperative) sectors in Hungary (see European Commission 2019 for more details). The relationship between the state and independent organisations in the country has always been characterised by cooperation as well as by mutual distrust and confrontation (Kuti 2008: 6). Currently, the relationship between the state and civil society is characterised by tendencies towards higher state control and clientelism (Kövér 2015).

\subsection{Legal Framework}

Voluntary social organisations, which can be regarded as the predecessors of associations and foundations, have existed in Hungary since the Middle Ages, while the first cooperative was founded in 1845. During the 40 years of state socialism (1949-1989), the establishment of foundations was prohibited, while some associations working in some politically neutral areas (such as sport and leisure) were allowed to function, and cooperatives came under state control. However, in the 1980s, due to the economic crisis and bankruptcy threatening Hungary, the strict, centralised system began to soften (Horváth 2010: 5).

Around the time of the regime change (in 1989), a first important step that facilitated the blossoming of the non-profit sector was the rehabilitation of foundations, in 1987. ${ }^{8}$ In 1989, the Act on the Right of Association was adopted. ${ }^{9}$ The new laws on foundations that were passed 
in 1990 made these organisations' operation financially more beneficial (Nagy 2011: 121). This led to an explosive growth in the number of organisations, and in particular of foundations, but it was not accompanied by a similar growth in the share of the population active in nonprofit organisations.

Cooperatives experienced a different path of development. Before the regime change, cooperative membership was more or less compulsory, and cooperatives were not autonomous, bottom-up initiatives launched and run by citizens (Kovách 2012: 33). In 1991-1992, the political elite launched a campaign against agricultural cooperatives, which were transformed into limited companies; within a few months, many ceased to exist (Kovách 2012: 67).

In the mid-1990s, three new non-profit organisational forms were created: public bodies, public foundations and public-benefit companies. ${ }^{10}$ In practice, these new types of organisation were larger than associations and foundations and were less independent from the state. Based on these the so-called "close-to-state" organisational forms, the outsourcing of public services started (Kuti 2008: 14), while the role of grassroots civilsociety organisations in service provision remained very limited (Bocz 2009: 36). The growth in the number of organisations slowed down, and a kind of "polarisation" of the sector begun.

The second half of the 1990s and first half of the 2000s were characterised by measures aiming at the institutionalisation and professionalisation of the non-profit sector and increased financial support to its organisations. Such measures included, for example the adoption of the 1\% Personal-Income Tax Law in 1996, ${ }^{11}$ the Public-Benefit Act of $1997^{12}$ or the 2002 Civil Strategy, followed by the creation of the National Civil Fund, in $2003^{13}$ (Nagy 2011: 121).

After the EU accession, which took place in 2004, with a view to reducing state control over public-benefit companies, the legal form of "non-profit company" was introduced (in 2006), ${ }^{14}$ and public-benefit companies were required to convert into this legal form. The legal form of social cooperative was also introduced in 2006; the creation of organisations of this type was linked in Hungary to EU-co-financed funding. ${ }^{15}$

After the change of government, in 2010, the new administration started to employ a less pluralistic, more centralising approach towards civil-society organisations (Márkus and Szabó 2015: 16). New pieces of legislation, passed in this period, mirror this trend. Although the new civil law, introduced in 2011, ${ }^{16}$ settled certain previously problematic legal relations, it also "raised many questions, resulting in uncertainty and confusion among CSOs on how to adapt to the new rules" (USAID 2013: 2). The new legislation of 2013 allowed all social cooperatives to include legal persons in their membership, such as local governments and charitable public-benefit organisations; ${ }^{17}$ in 2016, this law was amended, 
making the inclusion of such institutional members compulsory for all social cooperatives..$^{18}$ As a result thereof, local governments can now easily influence social cooperatives.

Most recently, in 2017, a new law on the transparency of organisations receiving support from abroad ${ }^{19}$ was adopted despite domestic criticism, demonstrations and international backlash. This law requires that associations and foundations receiving more than HUF7.2 million (around €20,000) in international support annually (not including EU funding) register at their local court as foreign-funded organisations, and make this status visible in all their communications.

Despite these alarming trends, the development of and support to social enterprise currently constitute a direct public-policy objective in Hungary. This is evidenced by the introduction, in 2016, of the first public-EU-co-funded-funding programme for social enterprises in the country.

\subsection{Possible Legal Forms}

There is no specific law or legal form for social enterprise in Hungary. The legal framework regulating organisations that can be considered as social enterprises is provided by laws on the different types of non-profit organisations and cooperatives (including social cooperatives), and especially by the New Civil Law of 2011.

According to the most recent data by the Hungarian Central Statistical Office, in 2017, there were 18,871 foundations and 34,742 associations (traditional civil-society organisations) in the country; the number of organisations among these that engaged in entrepreneurial activities was significantly lower, though. There were also 3,343 non-profit companies, and altogether 4,865 cooperatives, among which 3,005 were social cooperatives. ${ }^{20}$

Associations are allowed to carry out business activities, but only on a supplementary basis; such business activities should not jeopardise the association's main aim and should only be a means to achieve the economic conditions under which the organisation can pursue its main goal. As far as the allocation of profits is concerned, the association's assets can only be used in accordance with its basic aims, and profits may not be distributed to the members.

Foundations may not be established to pursue economic activities either. Similarly, to associations, they are only authorised to carry out economic activities directly connected to their main goal.

Non-profit companies are business companies, that is, "legal entities formed by the financial contribution of their members for a joint business-like economic activity, in which members collectively share the profits and collectively bear the losses" (Civil Code 3:88. \$). However, 
non-profit companies differ from ordinary businesses to the extent that the distribution of profits is not allowed in these organisations.

Cooperatives are for-profit organisations that aim to meet the economic and social needs of their members. Profit distribution is limited, as at least half of the cooperative's profits have to be distributed among the members. The social cooperative is the only legal form in Hungary intended specifically for social enterprise. Profit distribution is limited, similarly to what is the case in traditional cooperatives. However, due to the recent legal changes (see Section 3.1), social cooperatives have recently been losing their autonomy from the state.

Researchers disagree about whether social enterprises can have forprofit legal forms or not. The recent state programme that directly targets social enterprises only considers non-profit legal forms-with the exception of social cooperatives-as eligible to apply for the programme's benefits (Ministry for National Economy 2015: 6). It should be noted, though, that from the turn of the millennium onwards, "for-profit social enterprises have also appeared and they have become [ever] stronger" (Etchart et al. 2014: 6).

\subsection{Support Schemes and Programmes}

Support schemes and programmes connected to social enterprise in Hungary have mostly been co-financed through EU Funds, for example certain EU pre-accession funds before the accession and certain operational programmes and community initiatives after the accession, focusing mainly on the labour-market integration of vulnerable social groups and local economic development in disadvantaged areas (see G. Fekete et al. 2017; Kiss 2018 for more details). Besides programmes directly cofunded by the EU, certain initiatives fostering the development of SE-like activities were financed by the domestic state budget as well. ${ }^{21}$ Unfortunately, due to the small number of comprehensive impact assessments, the efficiency and results of these programmes are difficult to measure. Existing analysis often points out the deficiencies and lack of sustainable results of certain programmes (see European Commission 2019).

As of now, the main public funding schemes available are specified in the new Hungarian Partnership Agreement, where the term "social enterprise" appears beside those of "social economy", "transitional employment" and "sheltered employment" (Prime Minister's Office 2014: 31; for a detailed analysis, see Kajner and Jakubinyi 2015: 209-28). Within the Partnership Agreement, the Economic Development and Innovation Operational Programme (EDIOP), which is co-financed by the EU, aims-among other objectives-to support social enterprise and to facilitate NPOs' employment-generation projects. The "Programme for encouraging and supporting social enterprises", which is part of EDIOP, 
is the first programme targeting social enterprise in particular (Ministry for National Economy 2015: 6); within this Programme, non-profit organisations and social cooperatives receive funding, they can access interest-free loan, and they are offered professional support to employ underprivileged people in certain projects, but it is feared that the organisations might not be able to maintain these jobs when the funding comes to an end. Besides, another programme supporting the solidarity economy and community-supported agriculture also appears in the Rural Development Programme (RDP). Furthermore, a funding programme from domestic budget targeted social cooperatives with local governmental members and based on public employment ${ }^{22}$ (for more details on currently available funding opportunities, see European Commission 2019).

Besides the state (influenced by EU policies), which played a key role in supporting non-profit organisations and social cooperatives that contribute to the employment of disadvantaged, unemployed people, certain actors from both the non-profit and for-profit sectors have played an important role in shaping the field through providing financial or professional support to social enterprises. The role of networks and the academia should also be mentioned (see Kiss 2018; European Commission 2019 for more details).

International and domestic private foundations and other organisations directly focusing on social enterprise have also been present in Hungary for years. The most important of these support organisations, NESsT (a US-founded, international non-profit organisation) has been present in Hungary since 2001; it provides both capacity-building services and investment in the form of loans, capital investment and non-refundable grants. Another important organisation is Ashoka, the largest network of social entrepreneurs worldwide, which has been present in Hungary since 1995. Besides, recently, a range of new organisations have started to offer professional and sometimes financial support to social enterprises. ${ }^{23}$

Certain financial and other for-profit institutions have also been supporting social enterprises. These institutions typically offer funding, business education, pro-bono consultancy and other expert support as part of their CSR activities. ${ }^{24}$ Certain NGO funds-although they do not have a primary SE focus and rather aim to foster civil society in Hungarysupported projects with social entrepreneurial activities. ${ }^{25}$ There are also several competitions offering different types of prices (funding or professional development) for social enterprises, social-innovation projects or non-profit organisations in general. ${ }^{26}$

There are several networks and communities for certain types of social enterprise. ${ }^{27}$ The National Association of Social Enterprises aims to represent the interests of organisations that specifically define themselves as social enterprises. Besides, certain professional events, fairs and conferences have facilitated networking. In recent years, academic interest for 
social enterprise has also increased; several universities now offer courses and conduct research connected to the topic. ${ }^{28}$

\section{Main Challenges}

No database or recent representative study is available on social enterprise in Hungary. Existing literature mostly analyses statistics related to the non-profit sector ${ }^{29}$ or discusses qualitative case studies or quantitative research based on small samples. This makes any description of the sector in terms of number of enterprises, size, main activities and target groups difficult and the results unreliable. ${ }^{30}$

As already underlined earlier, there is no single and widely accepted definition of social enterprise in Hungary. The low level of awareness and understanding of the concept as well as the low level of trust of the general public in non-profit organisations performing economic activities hinder the emergence of the field (G. Fekete, Vicze et al. 2014; Etchart et al. 2014). It should also be noted that the concept was developed in contexts (US, Western Europe) that differ significantly from the one in Central and Eastern Europe.

There is no single law, uniform regulation or long-term strategy for the SE field, which contributes to a confusing legal and policy environment. According to Etchart et al. (2014: 10), the unpredictability of the regulatory environment has a negative impact on social enterprises.

Regarding finances, most of the social enterprises rely heavily on external - mostly public-financing (e.g. grants and subsidies), which constitutes a rather unpredictable source (since such financing is granted on an occasional basis) and is often scarce, bureaucratic, not based on local needs and lacks proper support infrastructure. Moreover, public funding is usually not tailored for the smaller organisations that are likely to be set up by groups of citizens. Though today there is substantial funding available for non-profit and civil-society organisations, certain organisations that are critical of current policies are not preferred, while others that envision development through means more acceptable to the current government might have privileged access to this source of funding (European Commission 2019). Funding explicitly intended for social enterprisesand co-financed by the EU-is also available (see Section 3.3), but it is restrictive in scope, focusing primarily on the work integration of disadvantaged groups. Certain state programmes specifically support social cooperatives with local governmental members, which pursue the work integration of people through the public-employment programme.

The Hungarian situation is also characterised by the low purchasing power of many consumers, especially in disadvantaged regions (G. Fekete, Vicze et al. 2014). In this respect, it should be underlined that although a stronger market orientation of Hungarian social enterprises 
appears desirable in several aspects, many social enterprises-especially among those emerging in disadvantaged regions-would most probably not be able to survive on the basis of market resources alone.

The lack of business and management skills of social entrepreneurs is also emphasised by some authors as a problem (Horváth 2010). However, this explanation places the responsibility on individuals without reflecting on the structures they are embedded in, such as Hungary's semi-peripheral position in the global economy, the uneven economic development within the country, or the approaches of the state, the EU and influential SE development organisations.

\section{Conclusion}

The concept of social enterprise-introduced in Hungary two decades ago- has recently started raising more interest. Similarly, to what is the case in other countries, the concept has several definitions and interpretations in Hungary. This stems from the diversity of approaches by various international and domestic development organisations and funds as well as from the different values and viewpoints of various stakeholders.

This conceptual diversity is also reflected in actual practices. In the framework of the present research, six models of social enterprise in Hungary were identified, namely public-service-provision social enterprises, enterprising CSOs, work-integration CSOs, local-development community enterprises, social start-ups and solidarity-economy initiatives. The major dimensions distinguishing the different models are the nature of the social aim (including employment), the economic opportunities and the sectoral affiliation of the initiatives, that is, the dominant sectors and interests at play, which also influence organisational autonomy and determine local relations.

Social enterprises' institutional context has been mainly influenced by the Hungarian state and the EU as well as by private international development organisations. Currently, there is an increase in public and private funding programmes, interested actors and public policy attention; this is due, to a large extent, to the priorities of the European Union. However, the available funding programmes have several shortcomings, and the legal and policy framework also lacks clear boundaries and comprehensive strategies for establishing the role of social enterprises in Hungary. The state is also playing a crucial role in the current polarisation of the sector through its support to certain activities (primarily work integration) and types of organisation and lack of support to others (e.g. it specifically targets social cooperatives in certain programmes, omits for-profits in others, and is hostile towards associations and foundations that receive funding from abroad).

Social enterprises face severe problems in their daily operation, due mostly to the unfavourable economic situation, unpredictable funding, 
deficient support infrastructure and confusing legal and policy environment. In addition to these barriers, since 2010, the relations between the state and independent organisations have been characterised by increasing levels of mutual distrust, which has contributed to the difficulties in the development of the SE field and also negatively impacts its future prospects.

\section{Tribute to Éva G. Fekete by the Other Authors}

In April 2017, our beloved colleague and mentor Prof. Dr. Éva G. Fekete passed away. Prof. G. Fekete was a respected and recognised researcher and practitioner of Hungarian rural development, a professor at the University of Miskolc and former head of the Northern Hungarian Department of the Centre of Regional Studies at the Hungarian Academy of Sciences. Throughout her work, Éva stood for the advocacy of the socially and spatially marginalised. She was one of the authors of the original working paper that inspired the present chapter, which was developed after her death.

\section{Notes}

1. The present chapter is the shortened version of the ICSEM Working Paper titled "Social Enterprise in Hungary" (G. Fekete et al. 2017). In the original paper, Prof. Éva G. Fekete was responsible for writing the section about "Social enterprise models", László Hubai for writing the section about "Possible legal forms", while Julianna Kiss and Melinda Mihály wrote all the other sections, taking into account the comments made by the other researchers. The chapter was adapted from the original text and updated by Julianna Kiss, Melinda Mihály and László Hubai.

2. For a review of the adaptability of the different concepts to the Hungarian context, see Mihály (2017) or Kiss (2018).

3. By "statutory", we mean that such support is not project-based, and that the right to this support is granted by law to all organisations providing a given service (e.g. employment of disabled persons).

4. "Social reproduction" should be understood here as referring to the process of reproducing social and ecological life; it is based on a logic that is independent and often contradicts capitalist accumulation processes but which, in a capitalist system, gets subordinated to the cycles of accumulation. This subordination happens not only through the exploitation of nature and the elimination of self-sufficient peasant societies or by shifting the burden of unpaid work on women but also through involving reproduction in the cycles of accumulation (Gagyi 2020).

5. The costs of capitalist accumulation are shifted onto society; the symptoms of a reproductive crisis include a high level of out-migration, a labour shortage, crises in the fields of care and housing, and the multiplication of informal subsistence solutions (Gagyi 2020).

6. See https://szolidarisgazdasagkozpont.hu/ (accessed on April 26, 2020).

7. A kaláka is a traditional reciprocity-based form of exchange of work, mainly used in harvesting or building family houses. It also has a 
community-strengthening function: after finishing the work, kaláka members often eat and/or celebrate together (Szabó 2008: 7). Even though kalákas are rooted in Hungarian traditions and would have the potential to contribute to the development of a solidarity economy, as a form of "de-politicised" informal work, they are essential for capitalist accumulation processes (Czirfusz et al. 2019: 15). Indeed, kalákas help capitalist accumulation through keeping the price of labour low by reducing households' expenditure (ibid.). However, if members of kalákas or other informal economic initiatives become aware of their political role, they may channel their work to the development of a solidarity economy, instead of channelling it to capitalist accumulation processes.

8. 11th Legislative Decree of 1987.

9. Act II of 1989 on the Right of Association.

10. Act XCII of 1993 amending the Civil Code.

11. Act CXXVI of 1996 on the Use of a Specified Amount of Personal-Income Tax for Public Purposes in Accordance with the Taxpayers' Instructions; this law allows taxpayers to offer $1 \%$ of their personal-income tax every year to civil-society organisations which they would like to support.

12. Act CLVI of 1997 on Public-Benefit Organisations.

13. Act L of 2003 on the National Civil Fund.

14. Act IV of 2006 on Business Associations.

15. Act X of 2006 on Cooperatives.

16. Act CLXXV of 2011 on the Right of Association, Non-profit Status, and Operation and Funding of Civil-Society Organisations.

17. Act XLI of 2013 Amending Various Laws Related to Social Cooperatives and Public Employment.

18. Act CXLV of 2016 on Modifying Certain Employment-related Laws.

19. Act LXXVI of 2017 on the Transparency of Organisations Receiving Support from Abroad.

20. See www.ksh.hu/business_units_and_nonprofit_organisatons_investments.

21. Non-profit employment programmes of the National Employment Foundation, later Non-profit Ltd. (OFA), and social land programmes.

22. Social cooperatives based on public employment are usually created by local municipalities. There are situations in which local governments that are implementing public-employment projects start a social cooperative and hire in this cooperative the workers that are still or were previously public employees. With a view to easing social tensions around socio-spatial inequalities and rural development, public policies have supported the emergence of such localgovernment-based social cooperatives and their merger with the public-work programme (Hamza et al. 2018). The public-work programme, however, often reproduces patron-client relationships between the local elite (e.g. the mayor) and the marginalised communities (European Commission 2019).

23. For example Civil Support and Badur Foundation.

24. For example the Erste SEED programme, UniCredit bank's “Social Innovation" competition, KPMG's (a leading audit, tax and advisory firm in Hungary) Programme for a Responsible Society and MagNet Bank's programmes.

25. This is the case of the EEA/Norway NGO Fund and the Swiss NGO Block Grant.

26. For example SocialMarie (since 2005) and the Added Local Value Award of the National Employment Public Limited Company (first organised in 2015).

27. For example the National Association of Social Cooperatives and the National Association of Charity Shops.

28. For example the Corvinus University of Budapest, the University of Debrecen, the University of Miskolc and the Eötvös Loránd Science University. 
29. Statistics are available for specific legal forms but not for social enterprises in particular.

30. Available data are to be extracted from data on enterprises, cooperatives and non-profit organisations. Regarding the number of social enterprises, due to the overall lack of statistics, only estimates are available, which range between 300 and 600 (Petheő 2009; NESsT 2014).

\section{References}

Ashoka (2015) Társadalmi vállalkozók. Available HTTP: http://ashoka-cee. org/hungary/t\%C3\%A1rsadalmi-v\%C3\%A1llalkoz\%C3\%B3k (accessed on August 19, 2016).

Avelino, F., Wittmayer, J. M., Pel, B, Weaver, P., Dumitru, A., Haxeltine, A., Kemp, R, Jørgensen, M. S., Bauler, T., Ruijsink, S. \& O’Riordan, T. (2019) "Transformative social innovation and (dis)empowerment", Technological Forecasting and Social Change, Vol. 145, pp. 195-206. Available HTTP: https://doi.org/10.1016/j.techfore.2017.05.002.

Bocz, J. (2009) “'Jéghegyek'. Tévhitek, avagy a magyar non-profit szektor mélyrétegei”, Civil Szemle, Vol. 6, No. 4, pp. 24-50.

Czirfusz, M., Csányi, G., Éber, M. Á., Gagyi, Á., Gerốcs, T., Jelinek, Cs., Katona, N., Kovai, C., Meszmann, T. T., Nagy, K., Pinkasz, A., Szarvas, M. \& Vigvári, A. (2019) "Szószedet a Fordulat 26. számához", Fordulat, Vol. 26, No. 2, pp. 5-27.

Etchart, N., Horváth, A., Rosandić, A. \& Spitálszky, A. (2014) The State of Social Entrepreneurship in Hungary, SEFORÏS Country Report, NESsT.

European Commission (2007) The Contribution of Social Capital in the Social Economy to Local Economic Development in Western Europe. Final report, Brussels: Directorate General for Research and Innovation, European Commission. Available HTTP: https://publications.europa.eu/en/publication-detail/-/ publication/f1f2eb4a-6506-4461-b180-7c20075b9ffb/language-en (accessed on August 19, 2019).

European Commission (2019) Social Enterprises and Their Ecosystems in Europe. Updated Country Report: Hungary (Authors: Kiss, J. \& Mihály, M.), Luxembourg: Publications Office of the European Union. Available HTTP: file:///Users/sophie/Downloads/Social\%20enterprises \%20and \%20their\%20 ecosystems \%20in \%20Europe. \%20Updated \%20country\%20report \%20Hun gary-1.pdf.

Frey, M. (2007) “A szociális gazdaság viszonyulása a hagyományos non-profit szektorhoz”, in Csoba, J., Frey, M., G. Fekete, É., Lévai, M. \& Soltész, A. (eds) Szociális gazdaság kézikönyv, Budapest: Pátria Nyomda Zrt., pp. 23-4.

G. Fekete, É. (2007) “A szociális gazdaság szereplői, partnerségépítés”, in Csoba, J., Frey, M., G. Fekete, É., Lévai, M. \& Soltész, A. (eds) Szociális gazdaság kézikönyv, Budapest: Pátria Nyomda Zrt., pp. 61-76.

G. Fekete, É., Hubai, L., Kiss, J. \& Mihály, M. (2017) “Social enterprise in Hungary", ICSEM Working Papers, No. 47, Liege: The International Comparative Social Enterprise Models (ICSEM) Project.

G. Fekete, É., Lipták, K., Osgyáni, G., Simkó, J. \& Siposné Nándori, E. (2014) "Lokális foglalkoztatáspolitika, a nem piaci foglalkoztatás jellemzói c. kutatás 
Zárótanulmánya”, Észak-magyarországi Regionális Kutatásokért Alapítvány (ÉMORKA).

G. Fekete, É., Vicze, M. \& Hámori, G. (2014) A Map of Social Enterprises and Their Eco-systems in Europe-Country Report: Hungary, Brussels: European Commission.

Gagyi, Á. (2020) "Szolidáris gazdaság és kapitalizmus. Az alternatív gazdaság új mozgalmi modelljei globális és magyar környezetben”, Fordulat, Vol. 27, No. 1, pp. 6-36.

Gagyi, Á., Kiss, J. \& Mihály, M. (2020) "Szószedet a Magyarországon használatos, a szociális és szolidáris gazdasággal kapcsolatos fogalmakhoz", Fordulat, Vol. 27, No. 1, pp. 292-8.

Hamza, E., Rácz, K., Szabó, D. \& Vásáry, V. (2018) “Szociális szövetkezetek szerepe a vidéki gazdaságban, avagy a Fókusz Támogatási program megvalósításának eddigi tapasztalatai”, Gazdálkodás, Vol. 62, No. 3, pp. 245-60.

Horváth, O. (2010) "Social economy in Hungary-national report", ISEDENET, Savaria Rehab-Team Non-profit Ltd.

Kajner, P. \& Jakubinyi, L. (2015) Szociális farmok létrehozása Magyarországon, Miskolc: Szimbiózis Alapítvány.

Kiss, J. (2018) A társadalmi vállalkozások megjelenése, intézményesülése és kapcsolódása a non-profit szektorhoz Magyarországon, Doctoral dissertation, Budapest: Eötvös Loránd Science University Faculty of Social Sciences (manuscript).

Kovách, I. (2012) A vidék az ezredfordulón. A jelenkori magyar vidéki társadalom szerkezeti és hatalmi változásai, Budapest: Argumentum; MTA Társadalomtudományi Kutatóközpont (Szociológiai Intézet).

Kövér, Á. (2015) "Captured by state and church: Civil society in democratic Hungary", in Krasztev, P. \& van Til, J. (eds) The Hungarian Patient. Social Opposition to an Illiberal Democracy, Budapest and New York: Central European University Press, pp. 81-90.

Kuti, É. (1998) Hivjuk talán non-profitnak . . A jótékonyság, a civil kezdeményezések és az állami keretból kiszoruló jóléti szolgáltatások szektorrá szervezódése, Budapest: Non-profit Kutatócsoport.

Kuti, É. (2008) "Stratégiai cselekvésen innen, illúziókon túl. Régi problémák és új kihívások Magyarország civil társadalmában és non-profit szektorában”, Civil Szemle, Vol. 8, No. 4, pp. 5-43.

Márkus, E. \& Szabó, M. (2015) "Civil society in Hungary", in Schreier, C. (ed) 25 Years After Mapping Civil Society in the Visegrád Countries, Berlin: Maecenata Institute for Philanthropy and Civil Society.

Mészáros, Z. (2013) "Közösségi gazdaságfejlesztés a gyakorlatban. Community economic development in the praxis", ACTA MEDSOC, Vol. 4, pp. 91-106.

Mihály, M. (2017) "Mit értünk társadalmi vállalkozás alatt és miért kutatjuk?Narratívák a nemzetközi szakirodalomból”, Észak-magyarországi Stratégiai Füzetek, Vol. 14, No. 1, pp. 101-15.

Ministry for National Economy (2015) Felhivás társadalmi vállalkozások ösztönzése-kiemelt projekt GINOP-5.1.2, Budapest: Nemzetgazdasági Minisztérium. Available HTTP: www.palyazat.gov.hu/ginop-512-trsadalmi-clvllalkozsok-sztnzse (accessed on December 6, 2017).

Nagy, R. (2011) “Mérföldkövek a non-profit szektor történetében”, Civil Szemle, Vol. 8, No. 4, pp. 119-31. 
Pataki, G. \& Radácsi, L. (2000) Alternatív kapitalisták. Gazdálkodás az érintettek jóllétéért, Budapest: Új Paradigma (Az Új vállalkozási kultúráért).

Petheô, A. I. (2009) A vállalati társadalmi felelösségvállaláson túl: a szociális vállalkozás, PhD thesis, Budapest: Budapesti Corvinus Egyetem.

Prime Minister's Office (2014) Magyarország Partnerségi Megállapodása a 2014-2020-as fejlesztési idôszakra, Budapest: Miniszterelnökség.

Szabó, Á. T. (2008) "Egy sajátos együttmúködési forma: a kaláka”, Örökségünk, Vol. 2, No. 3, pp. 6-7.

Tóth, L., Varga, É. \& Varga, P. (2011) A társadalmi vállalkozások helyzete Magyarországon, Budapest: NESsT.

USAID (2013) 2012 CSO Sustainability Index for Central and Eastern Europe and Eurasia, Washington, DC: United States Agency for International Development, Bureau for Europe and Eurasia, Office of Democracy, Governance and Social Transition.

Vágvölgyi, G. (2012) Towards community enterprise, Inspi-Ráció Association. Available HTTP: http://docplayer.hu/1098369-Kozossegi-vallalkozas-fele.html, www.youtube.com/watch?v=xUQQRb1hl6E (accessed on March 22, 2016). 